\title{
The Cost of COVID-19 on the Indonesian economy
}

\section{A Social Accounting Matrix (SAM) Multiplier Approach}

\author{
Angga Pradesha, Syarifah Amaliah, Anang Noegroho, and James Thurlow
}

Sustained economic growth and a declining trend in poverty over the years in Indonesia potentially will come to a halt this year. This development cost comes as a result of the COVID-19 pandemic outbreak that recently hit the country. Like in many other countries, one of the largest costs of COVID-19 comes from the social distancing policy, which is a proven public health measure to reduce the spread of the virus by limiting people's movements and interactions for a certain period of time. The government of Indonesia adopted this approach by gradually introducing in certain regions the Large-scale Social Restriction (PSBB) policy from early April 2020. PSBB restricts non-essential economic activities and people's movement in order to contain the virus. IFPRI, the National Development Planning Agency of Indonesia (BAPPENAS), and IPB University used a SAM multiplier model to measure the economic impact of PSBB if restrictions were to be in place for four weeks and to explore potential recovery processes after the policy ends. Some of the key findings were:

- National GDP is estimated to fall by 24 percent during the four-week PSBB period,

- External sector shocks - reduced export demand, lower remittances, and lower foreign investments - contribute around one-third of total GDP losses;

- The GDP of Indonesia's agri-food system falls by 13 percent despite agriculture activities being excluded from restrictive measures;

- National poverty is expected to jump by 13 percentage points - an additional 36 million people will fall into poverty during the four-week PSBB period; and

- By the end of 2020, due to COVID-19 the annual GDP growth is expected to be between 5.3 and 7.3 percent lower than under a baseline scenario without COVID-19.

\section{Introduction}

Indonesia's economy has enjoyed a period of long steady growth over the past decades coupled with declines in poverty. Gross Domestic Production (GDP) has been growing on average around five percent annually and is expected to be sustained in the future. With a long-term vision of being 
a developed nation in 2045, the government recently published the Medium-term National Development Plan 2020-2024 (RPJMN) that sets a target growth rate for the economy of close to six percent annually over the next five years. Annual per capita income is expected to surpass USD 6,000 and the national poverty headcount is projected to be less than seven percent by 2024 .

Unfortunately, the achievement of these development targets is now being challenged by the unprecedented COVID-19 pandemic that has spread globally and in Indonesia infected tens of thousands of people. As this Policy Note was being written, the trend in new COVID-19 cases in the country is still upward (Figure 1). After the first case was identified in early March 2020, the government immediately took important policy measures to contain the spread of the virus, including forming a special task force in mid-March to handle and coordinate government's effort to accelerate the mitigation of COVID-19 disease.

Figure 1. Confirmed new COVID-19 cases in Indonesia and timeline of policy response measures in 2020

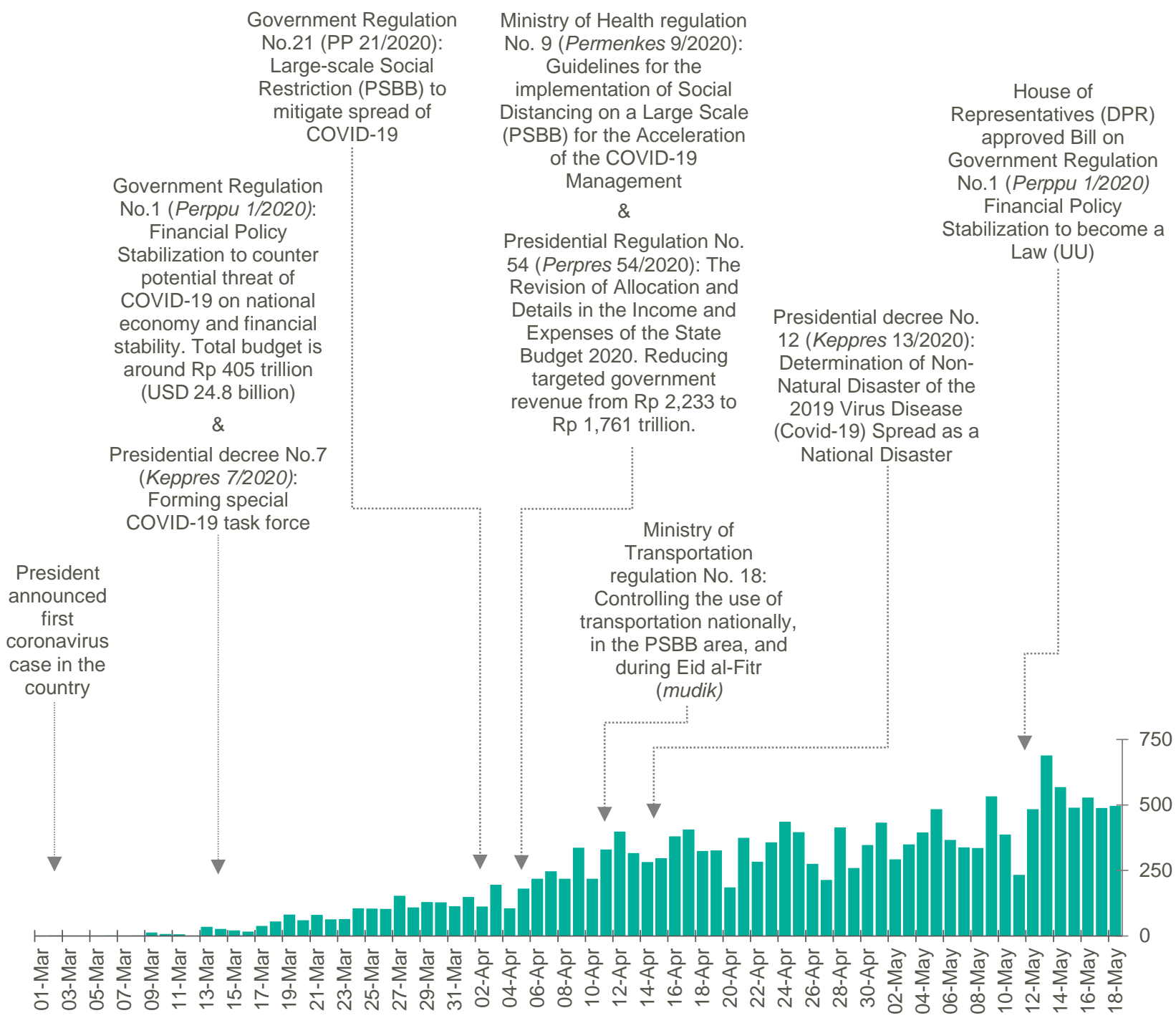

Source: Confirmed case data collected from https://kawalcovid19.id/

Around the same time, the government introduced the first government regulation (Perppu $1 / 2020$ ) to counter the potential threat of COVID-19 to the national economy and financial stability by providing a stimulus package at around Rupiah 405 trillion (USD 24.8 billion). This regulation was finally approved by the House of Representatives on May 12, affirming government's role in mitigating the impact of COVID-19 on the economy. Given expected lower economic growth 
ahead, in early-April the government also reduced the government revenue target for 2020 from Rupiah 2,233 trillion to 1,761 trillion.

After careful consideration, the government took bold action in early-April by implementing the Large-scale Social Restrictions $\left(\mathrm{PSBB}^{1}\right)$ policy in regions of Indonesia with high coronavirus caseloads. PSBB implementation has been regulated by the Ministry of Health in coordination with local governments. This public health measure is expected to reduce the spread of the virus and reduce the potential for larger economic losses in the future. The policy restricts non-essential activities, including the closure of schools and workplaces, sharply curtailing religious activities, halting non-essential public activities, such as concerts, imposing restrictions on hotels and other lodging, and limiting public transportation services. Restrictions on foreigners entering Indonesia were also imposed to prevent any further transmission of the virus from abroad - this was an extension of an earlier policy from early February that only applied to Chinese nationals or travelers from China. Government also introduced new domestic travel restrictions in order to limit the movement of people during Eid al-Fitr starting from early May.

This study assesses the potential economic cost of PSBB, as the policy is expected to slow economic activities and reduce household incomes. Global uncertainties that affect the country's external sector also are considered, such as declining trends in international trade and inflows of remittances and foreign investment. We estimate these costs using a Social Accounting Matrix (SAM) multiplier model. Such models are ideally suited to measuring short-term direct and indirect impacts of unanticipated, rapid-onset demand- or supply-side economic shocks, such as those caused by the COVID-19 pandemic. We also use the model to explore the economic impact of different speeds of recovery for the Indonesian economy as it bounces back after the PSBB policy is ended.

\section{Simulating the Economic Impacts of COVID-19}

We use a multisector multiplier model for the analysis, an approach which captures the complexity of an inter-connected economy. The SAM multiplier model builds on a SAM database that captures resource flows associated with all economic transactions taking place in an economy, the interlinkages across sectors, and relationships between economic actors and with the rest of the world. The model is based on a Social Accounting Matrix (SAM) of Indonesian economy, which describes the economic connections between actors of all sorts within the national economy and provides a highly disaggregated picture of the economy of 86 production sectors. We use the 2018 Indonesia SAM and scaled it up to represent the economy at the end of 2019 to permit an assessment of the likely impacts of COVID-19 in 2020, relative to 2019 values (base).

The SAM multiplier model provides a mechanism for estimating the effects of an external shock, typically an exogenous change in final demand for goods and services, on total supply of commodities. Through capturing input-output, employment relationships, and the functional distribution of income, the model also generates results on domestic production, employment, and changes in household incomes. The short-run analysis period assumes that technical input-output relationships, the output choices of producers, and the consumption patterns of households do not (yet) change in response to the simulated shock. Such behavioral responses are captured in general equilibrium models. However, the anticipated short-term nature of the COVID-19 shock and the likelihood that the economy will return to a "business-as-usual" state once the crisis dissipates makes the SAM multiplier framework more appropriate than general equilibrium models for analyzing this particular shock (Haggblade \& Hazell 1989; Round 2003; Breisinger et al. 2009).

\footnotetext{
1 "Large-scale social restrictions" in Indonesian translates as "Pembatasan Sosial Bersekala Besar" (PSBB).
} 
Table 1. Domestic sector COVID-19 related impact channels in Indonesia

\begin{tabular}{|c|c|c|}
\hline Sector & Lockdown restrictions of exemptions & $\begin{array}{l}\text { Impact } \\
\text { simulated }\end{array}$ \\
\hline Agriculture & $\begin{array}{l}\text { Farming activities are considered essential, so are exempted from most restrictions. } \\
\text { External trade shocks on export crops. }\end{array}$ & Minimal \\
\hline Mining \& crude oil & Mining activities are considered essential, so are exempted from most restrictions. & Minimal \\
\hline Manufacturing & $\begin{array}{l}\text { Food processing \& medicines exempted (essential sector). } \\
\text { Non-essential producing companies closed. } \\
\text { Limited access to production inputs from China. }\end{array}$ & High \\
\hline Utilities & Electricity \& water distribution exempted (essential sector). & Minimal \\
\hline Construction & Many public works programs reduced in affected areas. & Some \\
\hline $\begin{array}{l}\text { Wholesale \& retail } \\
\text { trade services }\end{array}$ & $\begin{array}{l}\text { Retailers of essential goods exempted. } \\
\text { Wholesale not exempted. }\end{array}$ & Some \\
\hline $\begin{array}{l}\text { Transportation, } \\
\text { storage \& cargo }\end{array}$ & $\begin{array}{l}\text { Air travel closed for all of May. Bus, train, and ship service hours limited and allowed } \\
\text { to operate only at half maximum capacity. } \\
\text { Ban on Eid al-Fitr related travel (mudik) from May } 7 \\
\text { Port cargo handling \& storage exempted }\end{array}$ & High \\
\hline $\begin{array}{l}\text { Hotels \& food } \\
\text { services }\end{array}$ & $\begin{array}{l}\text { Thousands of hotels closed. } \\
\text { Restaurant dining is strictly limited. }\end{array}$ & High \\
\hline $\begin{array}{l}\text { Banking, finance \& } \\
\text { insurance }\end{array}$ & $\begin{array}{l}\text { Money transfer services exempted (essential). } \\
\text { Banks operating with essential staff only. }\end{array}$ & Minimal \\
\hline Professional services & $\begin{array}{l}\text { Almost all closed or teleworking, e.g., legal and accounting services. } \\
\text { Activities involving in-person field visits sharply curtailed, e.g., engineers. }\end{array}$ & Minimal \\
\hline $\begin{array}{l}\text { Public administration, } \\
\text { law enforcement }\end{array}$ & $\begin{array}{l}\text { Public services and agencies remain open, but most staff teleworking. } \\
\text { Police \& security services exempted, as essential. }\end{array}$ & Minimal \\
\hline Education services & All schools closed, replaced by online learning. & Minimal \\
\hline Health services & Health services exempted (essential sector). & Minimal \\
\hline $\begin{array}{l}\text { Sports \& } \\
\text { entertainment }\end{array}$ & $\begin{array}{l}\text { Most sports \& outdoor entertainment banned. } \\
\text { Some activities operating, e.g., newspapers, radio and television stations. }\end{array}$ & High \\
\hline Other services & $\begin{array}{l}\text { In-person religious gatherings banned. } \\
\text { Major disruptions to informal repair firms due to market closures. }\end{array}$ & Some \\
\hline
\end{tabular}

Source: Author's compilation

Table 2. External sector COVID-19 related impact channels in Indonesia

\begin{tabular}{llc} 
External factor & \multicolumn{1}{c}{ Lockdown restrictions of exemptions } & $\begin{array}{c}\text { Impact } \\
\text { simulated }\end{array}$ \\
& $\begin{array}{l}\text { Decline in demand for exported goods. } \\
\text { Reduced international tourism \& business travel to Indonesia. } \\
\text { Lower export demand for agricultural and other primary products. }\end{array}$ & Some \\
Remittances & Decline in value of remittances sent by Indonesian nationals working abroad. & Some \\
Foreign investments & Fall in foreign investments due to uncertainty in global economic environment. & Some \\
\hline
\end{tabular}

Source: Author's compilation

We distinguish between domestic policy-induced impact channels (Table 1) and external impact channels (Table 2).

While the model is calibrated to national data, some of the COVID-19 containment measures only apply within specific regions. Java, Bali, and Sumatra are important commercial hubs in Indonesia that will be highly affected. Based on PSBB locations during the time of the study, many cities under the lockdown policy are on these three islands. We assume PSBB policy will affect the economy mostly in Java, Bali, and parts of Sumatra, covering around 70 percent of the total GDP for the country.

Underlying the 86 sectors in the SAM are more detailed supply-and-use data for 185 economic sectors in Indonesia. Therefore, in defining sector-level shocks across the 86 sectors, we consider implications of policy prescriptions at the more detailed 185 sector-level and estimate a weighted average shock that is applied to the relevant aggregated sectors in the model. 
The COVID-19 easing and recovery scenarios. We designed two model scenarios to examine how fast the Indonesian economy might bounce back as a recovery process comes into play through the rest of 2020. The policy shock from PSBB is introduced in the second quarter of the year and extends through quarter four, but with different magnitudes by scenario. Following the PSBB period, we assume policy measures are either lifted quickly, resulting in a fast recovery, or gradually, resulting in a slow recovery (Table 3 ). The fast and slow scenarios may equally represent a scenario where economic actors, due to health concerns, are slow to return to a business-as-usual scenario even as restrictions are fully lifted.

Table 3. Easing of restrictions and recovery model scenarios by quarter of 2020

\begin{tabular}{|c|c|c|c|c|}
\hline \multirow{3}{*}{ Q1 } & & Faster easing & Slower easing & Global shocks \\
\hline & Jan \& Feb & \multicolumn{3}{|c|}{ No shocks in the pre-COVID-19 period } \\
\hline & Mar & \multicolumn{2}{|c|}{ Economic disorganization prior to the partial lock down } & \multirow{2}{*}{$\begin{array}{l}\text { - Remittances \& export demand } \\
\text { decline from } 1^{\text {st }} \text { March }\end{array}$} \\
\hline \multirow[t]{2}{*}{ Q2 } & Apr to early-May & \multicolumn{2}{|c|}{$\begin{array}{c}\text { PSBB lockdown period in selected areas in } \\
\text { April and May for } 4 \text { weeks }\end{array}$} & \\
\hline & Late-May to Jun & $\begin{array}{l}\text { Production losses from } \\
\text { lockdown policies fall } 80 \%\end{array}$ & $\begin{array}{l}\text { Production losses from } \\
\text { lockdown policies fall } 50 \% \\
\end{array}$ & Shocks reduced by $50 \%$ \\
\hline Q3 & Jul to Sep & Losses reduced by $90 \%$ & Losses reduced by $75 \%$ & Shocks reduced by 75 to $80 \%$ \\
\hline Q4 & Oct to Dec & Losses reduced by $95 \%$ & Losses reduced by $90 \%$ & Shocks reduced by 90 to $95 \%$ \\
\hline
\end{tabular}

Source: Author's compilation

\section{Simulation Results and Discussion}

\section{Economic impact during PSBB lockdown period}

We first consider the economic impact during the four-week PSBB lockdown period. Figure 2 shows the impact on aggregate GDP and its components. The largest losses, in absolute and relative terms, are recorded in the industry (-23.4 percent) and services (-29.7 percent) sectors, which contribute over 90 percent of the recorded 24.3 percent loss in national GDP during the lockdown period (left panel). This is equivalent to USD 26.4 billion in lost GDP during a four-week lockdown period (right panel). If government decides to extend the PSBB period, every added week would cost the economy around USD 7 billion in lost GDP.

Figure 2. Change in GDP by economic sector during the four-week PSBB lockdown and under hypothetical extensions of the lockdown period

Change in GDP by sector during four-week lockdown period, \%

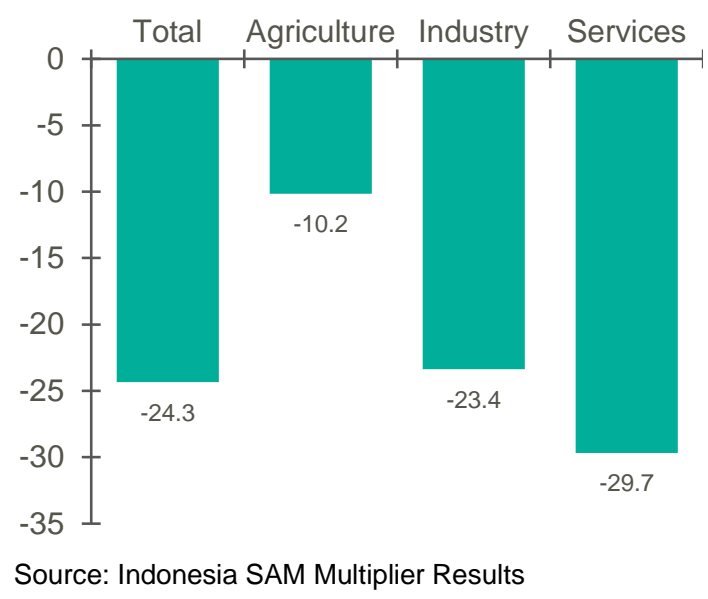

Change in total GDP by duration of lockdown, USD billions

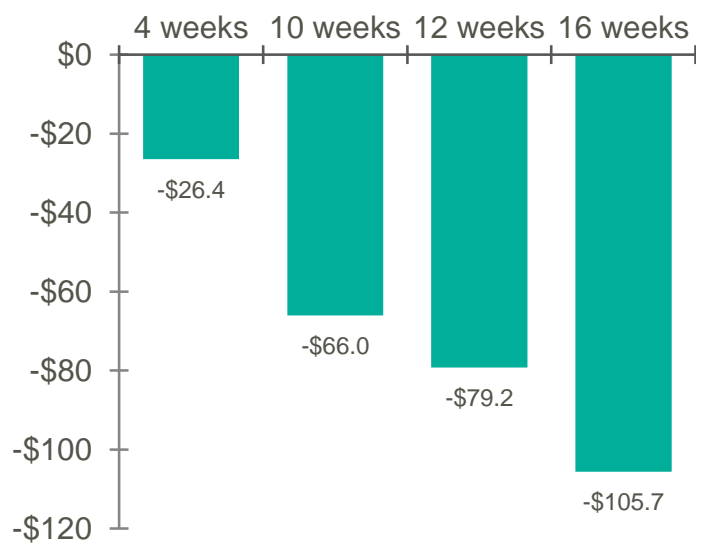

Figure 3 provides a breakdown of the contribution of different impact channels (Table 1) to total GDP losses. The relative contributions of these impact channels depend on the severity of the 
lockdown measures, the geographical scope of their implementation, the size of the cluster of sectors represented within each impact channel, and the extent of the economic linkages that exist between affected sectors and other sectors. The severe restrictions imposed on non-essential service sectors, such as transport and trade services, contribute about one-third to overall losses.

Figure 3. Contribution of restrictions and shocks to GDP losses during the PSBB lockdown, by impact channel, percent of total GDP losses

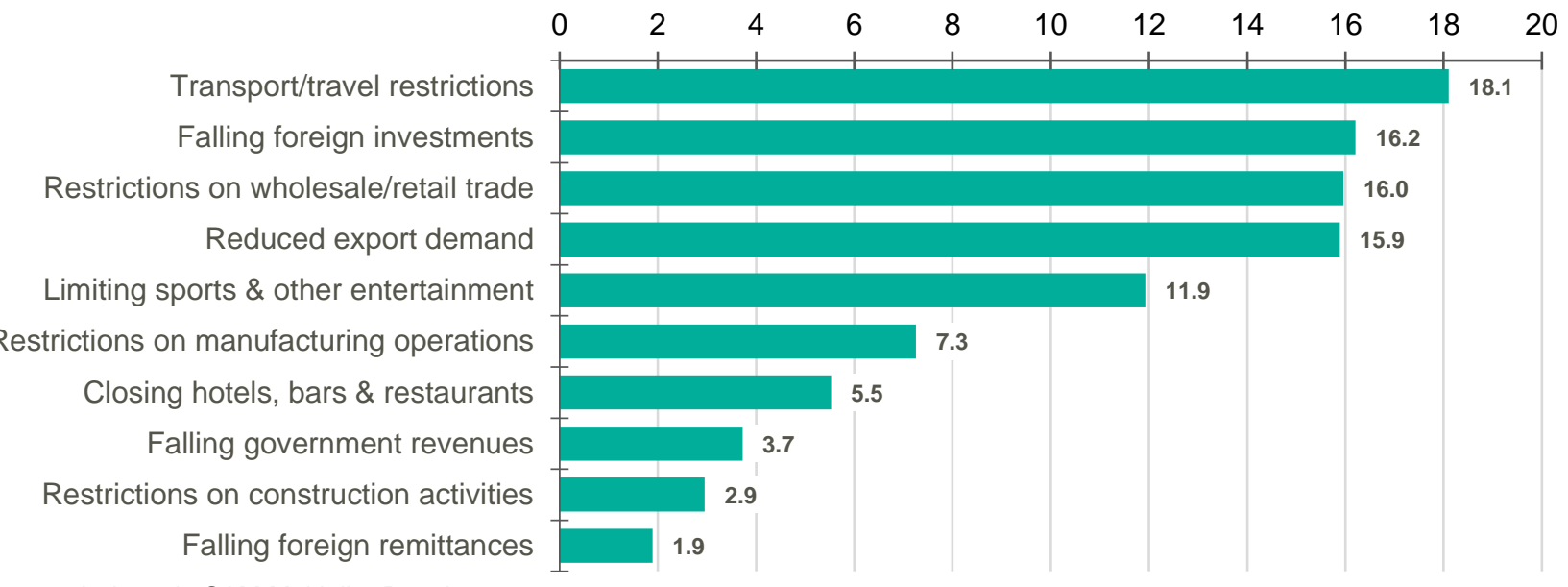

Source: Indonesia SAM Multiplier Results

The impact of external sector factors originating from reductions in foreign investment, export demand, and remittances also has a sizable effect on GDP, contributing to another one-third of total losses. Closure of entertainment facilities and cancelation of public events further contributes to 10 percent of GDP losses. Similar levels of impact come from restriction on manufacturing operations and closing of hotels and restaurant. Falling government revenue and restriction on construction activities are responsible for the remaining losses. This sectoral contribution also shows that the disruption emanating from global the economy (external sector) is quite sizeable in comparison to the damage caused by suspension of many domestic activities under PSBB.

Although primary agricultural activities are excluded from direct restrictions, the agricultural sector is not shielded from adverse effects of the lockdown, with agricultural GDP falling by 10.2 percent (Figure 4). These unintended knock-on effects of policies highlight the importance of using a model framework that explicitly captures inter-industry linkages and measures indirect effects. To understand the significance of these inter-industry linkages better, it is useful to consider effects along the entire agri-food system (AFS). The AFS accounts for 30.8 percent of GDP in Indonesia and consists of primary agriculture, agro-processing, food services (hotels and restaurants), and food trade and transport services. Figure 4 shows that AFS GDP losses amount USD 4.3 billion or 12.6 percent.

Figure 4. Change in agri-food GDP by component during the PSBB lockdown

Change in \%

Change in USD billions

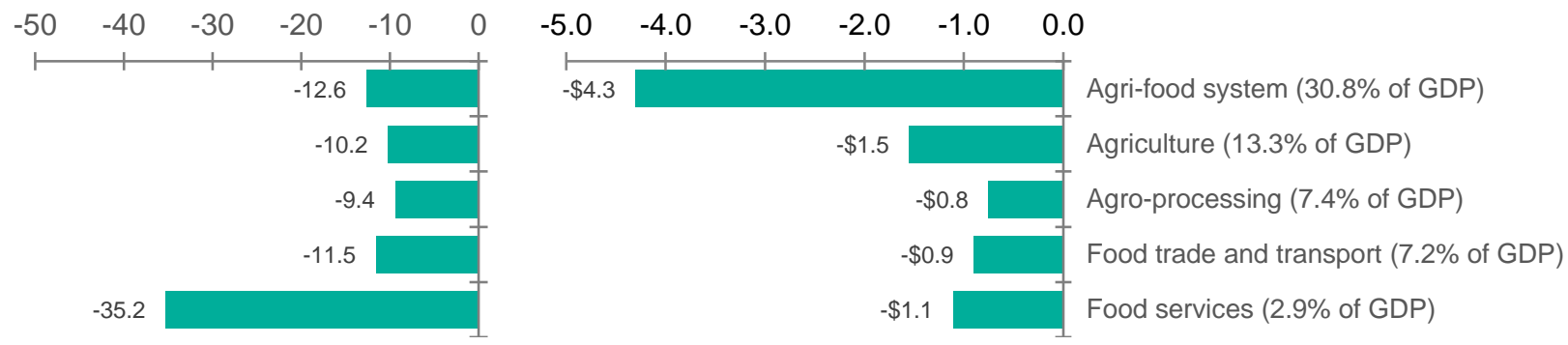

Source: Indonesia SAM Multiplier Results.

Note: Figures in brackets next to row labels show each agri-food component's contribution to Indonesia's total national GDP. 
With respect to losses within each AFS component, we find that the food services sector, which is affected directly by social distancing measures and reduced patronage due to the fall in tourism, not only declines significantly in relative terms (-35.2 percent), but also accounts for a large share of overall AFS GDP losses, despite being a relatively small subsector. Figure 5 provides a breakdown of the contribution of different impact channels to AFS GDP losses. Reduction in export demand, mainly driven by reduced exports of agricultural commodities, also contributes to a reduction in agriculture sector GDP. However, the substantial effect of restrictions on hotel and restaurant operations on the food system cannot be ignored, which reconfirms the importance of tracking inter-industry linkages across the agri-food system.

Figure 5. Contribution of restrictions and shocks to GDP losses in Indonesia's agri-food system during the PSBB lockdown, by impact channel, percent of agri-food system GDP losses

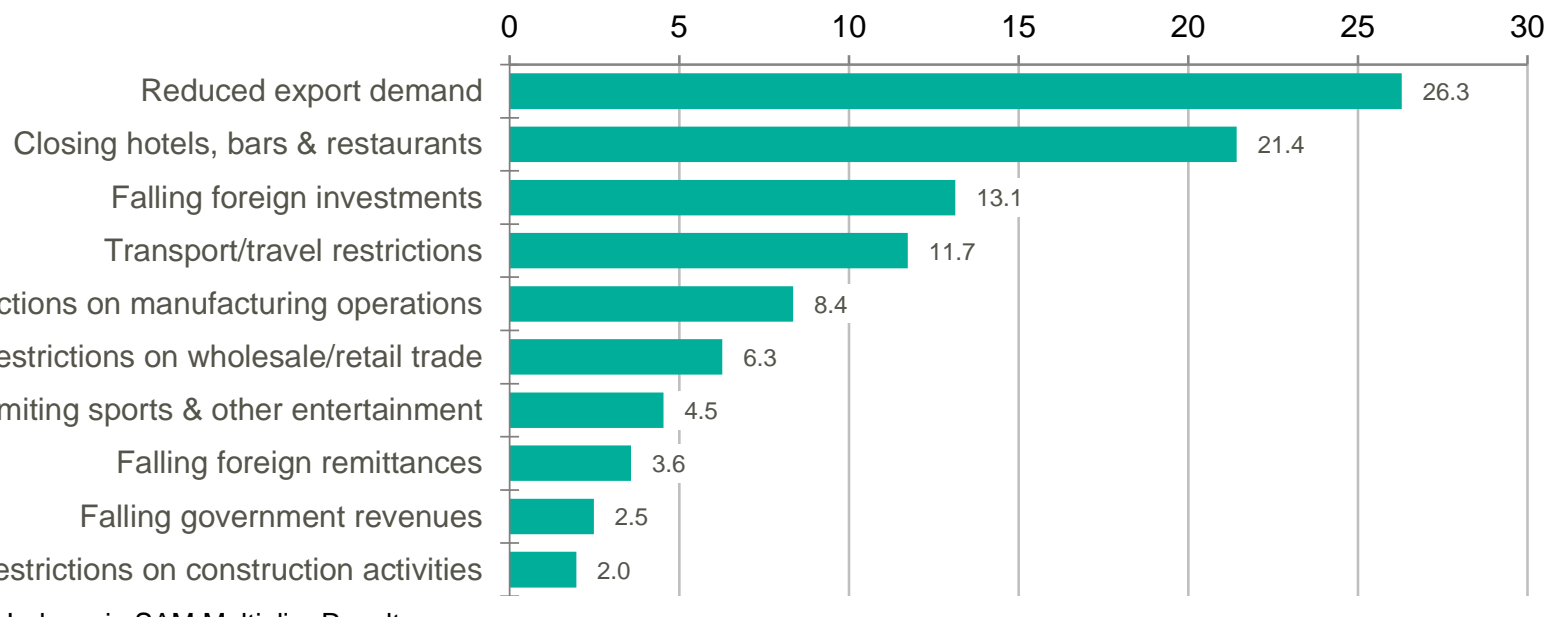

Source: Indonesia SAM Multiplier Results.

Given that the lockdown hits many production and trade sectors, household incomes are affected primarily via employment income losses and, to a lesser extent, via falling foreign remittances. As shown in Figure 6, average household income falls by 24 percent during the lockdown period. Higher-income households slightly suffer more than their lower-income counterparts, which reflects the ties of wealthier households to formal sector job markets, particularly in the manufacturing and services sectors, which are more severely affected by lockdown measures. In terms of location, the PSBB primarily affects urban households and rural non-farm households. Rural farm households, on the other hand, are less severely affected by the PSBB policy given that their income mainly comes from the agriculture sector, which is exempt from PSBB restrictions. Despite that, they are still subject to social distancing measures directly through transport restrictions and indirectly via the external sector effects and spillover effects of urban lockdown measures into the agri-food system.

Figure 6. Change in household incomes during the PSBB lockdown, percent

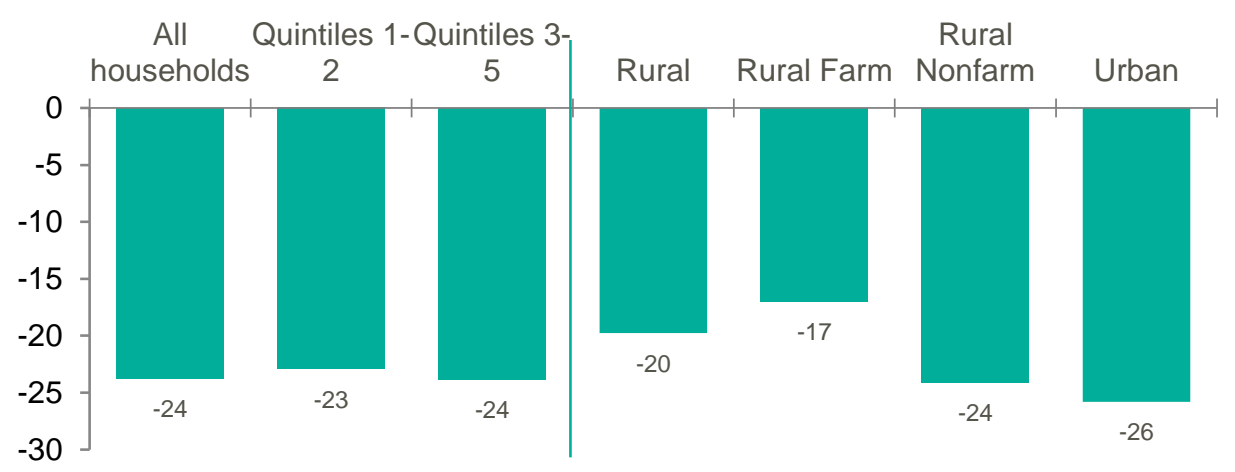

Source: Indonesia SAM Multiplier Results 
Figure 7 reports on the impact on poverty levels given the income reduction observed across households. In generating poverty estimates, we assume that a production slowdown translates into a decline in employment income. In reality, some employers would have continued to pay workers during lockdown or households would have been able to draw on savings to sustain consumption. As such, our result may overstate the actual experience of being poor, i.e., from the perspective of people's ability to access food. It, nevertheless, shows the impact of the shock in terms of wage incomes or profits foregone. We find that the national prevalence rate of poverty increases 13.3 percentage points, which equates to 35.9 million more people falling below the poverty line during the four-week PSBB lockdown period. Rural households are only slightly shielded from negative income shocks compare to their urban counterparts.

Figure 7. Change in number of poor people and in poverty rate during the PSBB lockdown

Change in number of poor people, Change in poverty headcount, millions
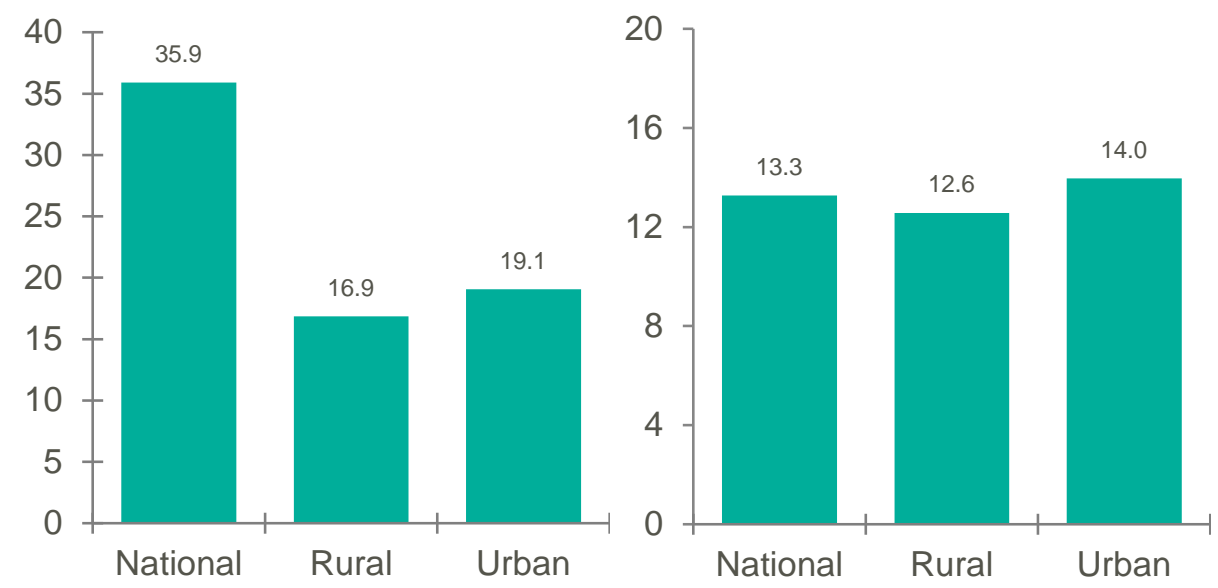

Source: Indonesia SAM Multiplier Results

\section{Annual economic impact of COVID-19 under fast and slow recovery scenarios}

Based on the impact of the four-week lockdown period discussed above, we then measure the likely annual impacts of COVID-19 under the two scenarios presented earlier in Table 3. The fast recovery scenario assumes restrictive measures are quickly lifted and business activities rapidly return to pre-crisis levels. The slow recovery scenario assumes a more gradual easing up of restrictions and a more tentative return to business-as-usual.

The differing impacts of these scenarios on GDP relative to a baseline scenario without COVID-19 are shown in Figure 8. As the effects of COVID-19 were only beginning to be felt in March, primarily through external sector channels, the overall drop in GDP in quarter one (Q1) is minimal (-2.0 percent). The largest impact is felt in the second quarter (Q2) during the PSBB lockdown period, with an average loss of between -13.2 and -16.2 percent in quarterly GDP. This means that if Indonesia's GDP in Q2 had been expected to grow by 5 percent, then what we will observe is net negative GDP growth of between 8.2 and 11.2 percent in the second quarter of 2020. 
Figure 8. Change in Indonesia's GDP relative to baseline under COVID-19 recovery scenarios in 2020

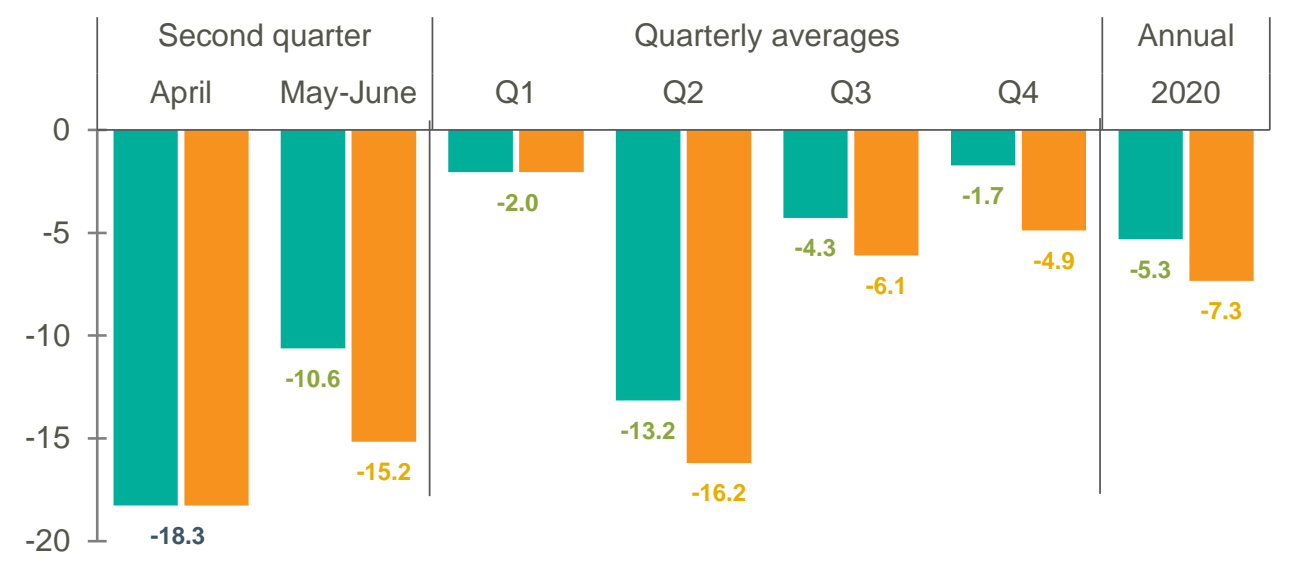
Faster lifting of
restrictions
Slower lifting of
restrictions

Source: Indonesia SAM Multiplier Results

In our model scenarios, we assume that economic recovery from the PSBB lockdown shock begins in May. Further easing of COVID-19 related restrictions in the third (Q3) and fourth (Q4) quarters result in losses ranging from -4.3 to -6.1 percent and from -1.7 to -4.9 percent, respectively. Depending on the speed of recovery, our estimated weighted average loss in GDP for the 2020 calendar year ranges from -5.3 to -7.3 percent. This means that, compared to an estimated growth rate in 2020 without COVID-19 of 5 percent, this year annual GDP growth is expected to be negative between -0.3 and -2.3 percent. The economic growth projections for 2020 of the government are 2.3 percent. Our less optimistic outlook on the rate of economic growth in 2020 is primarily explained by the fact that our SAM multiplier model framework captures both the direct and the indirect effects of COVID-19 on Indonesia's economy.

Figure 9. Change in poverty headcount relative to baseline under COVID-19 recovery scenarios in 2020 , percentage points

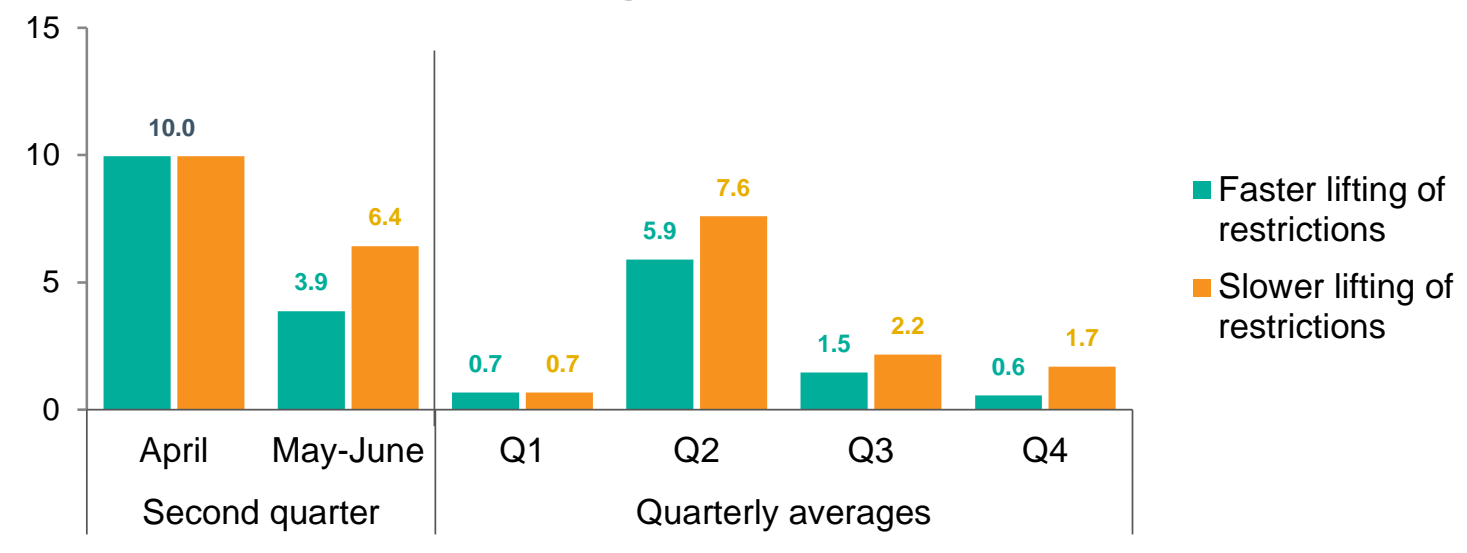

Source: Indonesia SAM Multiplier Results

Compared to the high increase in the incidence of poverty during the PSBB period in the second quarter, Figure 9 shows how the poverty rate gradually returns to the baseline (or precrisis) poverty rate during Q3 to Q4. By the end of the calendar year, the poverty rate will likely be between 0.6 and 1.7 percentage points higher than under the baseline. Nonetheless, there will be millions of people who fall into poverty and many vulnerable households will suffer during the second and third quarters of 2020.

This situation demands strategies to improve the chances of these vulnerable groups escaping from poverty by the end of the year. Future analysis should consider the likely mitigating impact of government household support programs, which include subsidized electricity bills and cash transfer programs to targeted households. Such analyses should also consider seasonality effects 
that determine household income and consumption pattern over the remaining quarters of 2020 as well as seasonal patterns in the economic activities that take place in rural and urban areas.

\section{Conclusions}

This study estimates the economic costs of COVID-19 in Indonesia with respect to economic output and value-added, household income, and poverty using a Social Accounting Matrix (SAM) multiplier model. Results from the multiplier model show that the PSBB lockdown policy, despite being implemented for a relatively brief period and only in certain regions, will impose heavy economic costs.

National GDP is estimated to fall by 24.3 percent during the four-week PSBB period. Even though the impact mainly comes from the suspension on manufacturing and service sector activities, the contribution of external sector factors is still sizable, accounting for one-third of total GDP losses. The sectoral interlinkages that characterize Indonesia's agri-food system also creates sizable GDP losses within the agriculture sector, even though farming activities are largely excluded from restrictions under PSBB policy. As lockdown measures are officially lifted, some restrictions, e.g., social distancing or border closures, are expected to remain in place for longer. Moreover, businesses may be slow to restart their operations and reach pre-crisis production levels. Under our fast and slow recovery model scenarios, we estimate that annual GDP growth in 2020 will be 5.3 to 7.3 percent lower than the baseline due to COVID-19. This means that the GDP growth in year 2020 could potentially be negative.

The production slowdown during the PSBB lockdown period translates into an immediate decline in employment income and an increase in national poverty by 13.3 percentage points. This substantial increase, albeit temporary, translates into an additional 35.9 million people falling into poverty during the four-week PSBB period. During the rest of 2020, as households' current incomes recover to (almost) pre-crisis levels, the national poverty rate will be between 0.6 and 1.7 percentage points higher than at the start of the year. While the expected recovery is good news for households, millions of people will experience temporary hardships, especially during the second and third quarter, and will likely require government support.

Further analysis is needed to assess the impact of household support measures that have already been announced. However, the program should not be biased towards urban households alone - our results show that almost half of households that become poor during the PSBB period are rural households. Special support measures for the food system are also called for - not only to protect rural farm livelihoods, but to ensure stable and safe food supplies across value chains. Long-term investment in Indonesia's agriculture and food systems is also essential to improve economic and household income resiliency against any potential major shocks in the future. 


\section{References}

Breisinger, C., M. Thomas, \& J. Thurlow. 2009. Social accounting matrices and multiplier analysis: An introduction with exercises. Food Security in Practice Technical Guide 5. Washington D.C.: International Food Policy Research Institute.

Haggblade, S., \& P. Hazell. 1989. "Agricultural technology and farm-non-farm growth linkages." Agricultural Economics, 3 (4): 345-364.

Round, J. 2003. "Social Accounting Matrices and SAM-based Multiplier Analysis." In F. Bourguignon \& L. Pereira da Silva, eds. Techniques and Tools for Evaluating the Poverty Impact of Economic Policies. Washington DC: World Bank and Oxford University Press.

\section{ABOUT THE AUTHORS}

Angga Pradesha is a Senior Research Analyst in the Development Strategy and Governance Division (DSGD) of the International Food Policy Research Institute (IFPRI), based in Washington, DC, USA. Amaliah Syarifah is a lecturer in the Faculty of Economics and Management at Institut Pertanian Bogor (IPB University), based in Bogor, Indonesia. Anang Noegroho is Director of the Food and Agriculture Division of the National Development Planning Agency of Indonesia (BAPPENAS), based in Jakarta, Indonesia. James Thurlow is a Senior Research Fellow in DSGD of IFPRI, based in Washington, DC, USA.

\section{ACKNOWLEDGMENTS}

The CGIAR Research Program on Policies, Institutions, and Markets (PIM) and the United States Agency for International Development (USAID) provided funding for this study. 